\title{
Using of Shell Filtering Constructions for Concentrating Plant's Coal Slurry Dewatering
}

\author{
Elena Murko ${ }^{1, *}$, Valentin Kalashnikov ${ }^{2}$, Anton Gorbachev ${ }^{2}$, and Igor Mukhomedzyanov ${ }^{3}$ \\ ${ }^{1}$ T.F. Gorbachev Kuzbass State Technical University, Department of Postgraduate and Doctoral \\ Studies, 650000 Kemerovo, 28 Vesennyaya st., Russian Federation \\ ${ }^{2}$ JSC «SUEK-Kuzbass», 652507 Leninsk-Kuznetsky, 1 Vasil'eva st., Russian Federation \\ ${ }^{3}$ T.F. Gorbachev Kuzbass State Technical University, Mining Institute, 650000 Kemerovo, 28 \\ Vesennyaya st., Russian Federation
}

\begin{abstract}
The urgency of using mining waste is also emphasized by the environmental component: reducing the anthropogenic load on the region through the integrated development of mineral resources with an increase in the waste-free component of technological processes will undoubtedly improve the difficult environmental situation in Kuzbass. This will be reflected in the reduction of pollution of surface and groundwater, the atmosphere, the soil, the reduction of the land capacity of mining enterprises by reducing the area occupied by the treatment facilities. The study of the state of the issue of coal sludge dewatering showed that at present there is no unified technology of dewatering using geotextile materials (Geotube ${ }^{\circledR}$ etc.). With the general similarity of existing technologies, there were no uniform requirements for the preparation of raw materials, the site for work, the type, properties and parameters of the geotextile used, etc., which makes it difficult to apply this or that technology in industrial conditions and large-scale coal sludge. Thus, the purpose of this study is to select the most optimal geotextile material (in terms of price / quality ratio) and to develop a technological scheme for the dewatering of water-coal pulp formed in the radial thickener of the concentrating plant.
\end{abstract}

\section{Introduction}

The technology of mine water purification from suspended particles at the last stage involves the transfer of sediment to the sludge collector. This stage is a rather laborious and organizationally difficult process, accompanied by the cessation of filling the primary settling pond, its drying, subsequent washing-out of the watered sludge and pumping the pulp into the slurry dump. When working according to this scheme, a man-caused (technogenic) coal deposit is formed in the sludge collector, which is actually a waste from underground coal mining. This paradox arises from the fact that in the course of the impact of the working body of the mining equipment on the coal seam, fine coal dust is formed,

\footnotetext{
*Corresponding author: zhev.httte@kuzstu.ru
} 
which, mixing with the water supplied to the mine workings, is removed from the mine during the drainage process, leaving the coal mining process.

\section{Materials and methods}

The use of geotextiles for various purposes has been the subject of a large number of works, among which [1-13] can be distinguished, but the question of using geotextiles for coal slurry dewatering for later use has not been considered. This article attempts to partially fill this gap.

Depending on the grade of the original coal, the following products can be obtained from coal sludge: a combustion concentrate (boiler fuel) [17], semi-coke, coke, sorbents, etc. from the organic part; rare, rare earth and trace elements, magnetite, components for building materials, etc. from the mineral part. Clarified water from solid particles can be returned to the production cycle.

The proposed technological scheme for processing and utilization of coal sludge (coal pulp) proposed in [14-16] involves the use of a coal slurry with a solids content of 56-60\% (concentration about $600 \mathrm{~g} / \mathrm{l}$ ) with further coal cleaning using the oil agglomeration method. To reduce the moisture content of the feedstock sent for cleaning by the above method, as well as the sludge formed during the settling of process water, it is possible to include a dewatering process in the proposed scheme (Fig. 1).

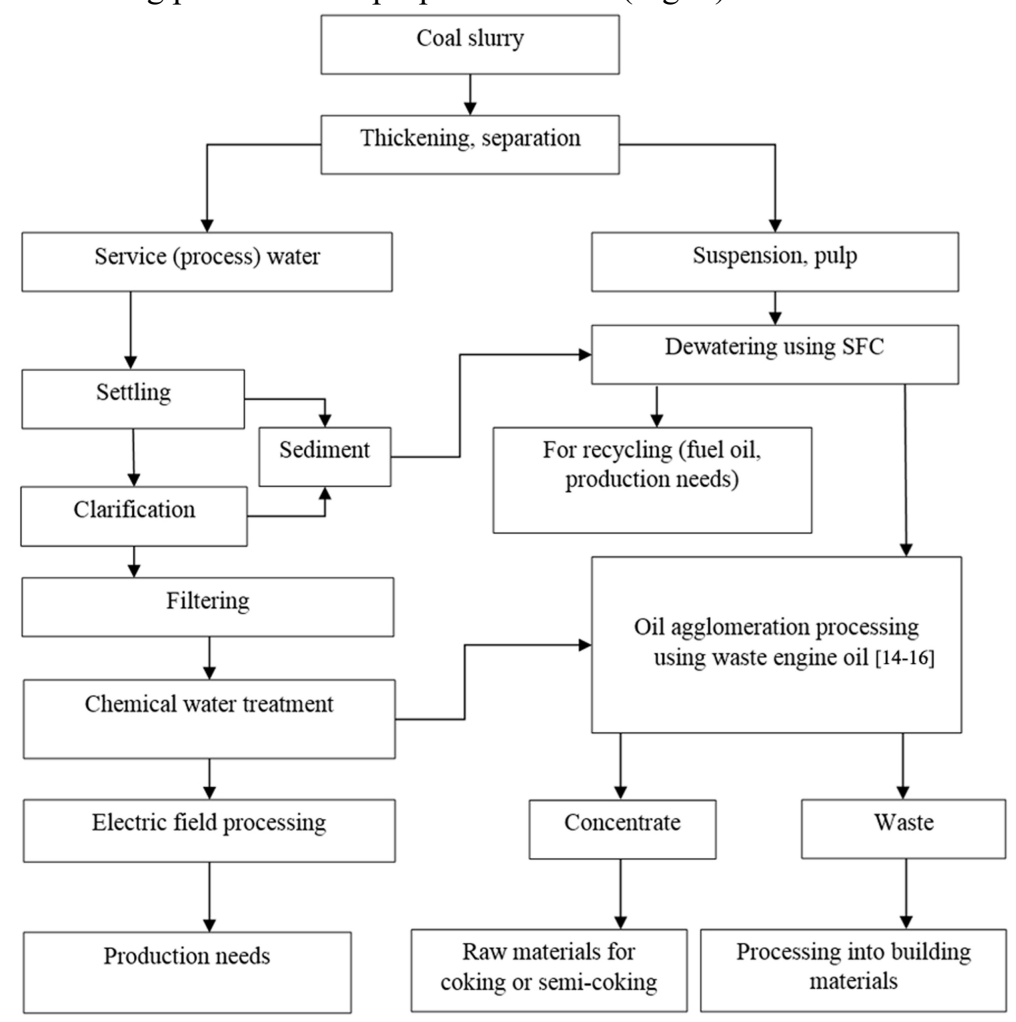

Fig. 1. Scheme of processing coal slurry and process water treatment.

In the absence of the necessary conditions for conducting field experiments (bad weather conditions, the inability to remove and collect the filtrate, the inability to conduct 
observations, etc.), it is possible to study various geotextile (geotextile-like) materials in the laboratory.

To do this, at work sites (sludge lagoon, radial thickener), samples of water-coal pulp are collected in hermetic containers and transported to the laboratory. Next, the pulp is loaded into the laboratory-scale plant with a fixed sample of geotextiles. An example of the laboratory-scale plant design is shown in Fig. 2.

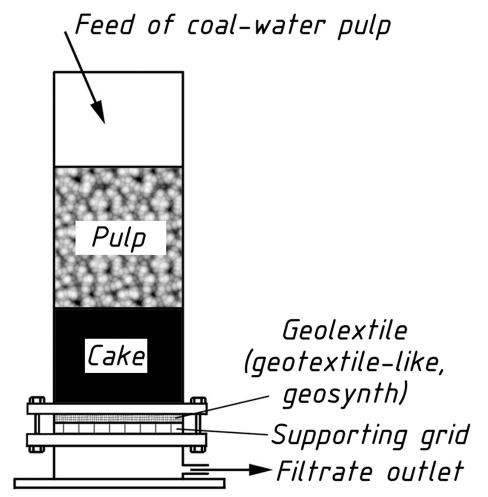

Fig. 2. Laboratory-scale plant for the study of the filtering properties of geotextiles.

\section{Results}

For carrying out pilot work, shell filtering constructions (SFC) with a capacity of up to 50 liters of geotextile-like and geotextile materials were manufactured as starting prototypes:

1) polypropylene sacking (density $\rho=83 \mathrm{~g} / \mathrm{m}^{2}$ );

2) tarpaulin (burlap) (density $\rho=367 \mathrm{~g} / \mathrm{m}^{2}$ );

3) non-woven fabric (density $\rho=149 \mathrm{~g} / \mathrm{m}^{2}$ );

4) non-woven fabric "Megaspan Agro 42" (density $\rho=35 \mathrm{~g} / \mathrm{m}^{2}$ );

5) non-woven geotextiles "Geotech 250" (density $\left.\rho=230 \mathrm{~g} / \mathrm{m}^{2}\right)$;

6) non-woven geotextiles "Geotech 350" (density $\rho=300 \mathrm{~g} / \mathrm{m}^{2}$ ).

The criteria for the selection of these materials were:

- water and air permeability;

- pore size comparable to the size of the floccules of water-coal pulp from the radial thickener;

- availability for purchase on the market of small batches for the purpose of manufacturing a limited number of samples.

The filling of the test SFC, both under the radial thickener and near the sludge lagoons, was carried out manually. Approximately 25-30 liters of water-coal pulp with a moisture content of $\mathrm{W}=131.25 \%$ was placed in each tank. After the formation of a small volume of the slurry body inside the starting SFC and its partial dehydration with the formation of a cake crust 20 days later and 40 days after the SFC was filled with pulp, the cake was sampled from the starting SFC under the radial thickener. Visually, it was noted that the outer part of the slurry body, directly adjacent to the surface of the SFC, has a lower humidity than the inner part.

As a result of the conducted experiments, it was revealed that the degree of dewatering of water-coal pulp for some materials is different; the moisture content of the cake samples is presented in fig. 3 in the matrix form.

A preliminary analysis of the matrix showed that the highest quality in terms of dewatering rate (dewatering for 20 days to a moisture content of $\mathrm{W}<50 \%$ ) from the entire 
range of materials are materials that fall into matrix III and IV of the matrix - №5 (Geotech 350), №2 (Geotech 250) and №6 (tarpaulin). At the same time, the cheapest (matched I and III quadrants of the matrix) in order of increasing cost are materials Nos. 1, 3, 4, 5, 6 (polypropylene fabric, Megaspan Agro 40, nonwoven fabric, Geotech 250, Geotech 350).

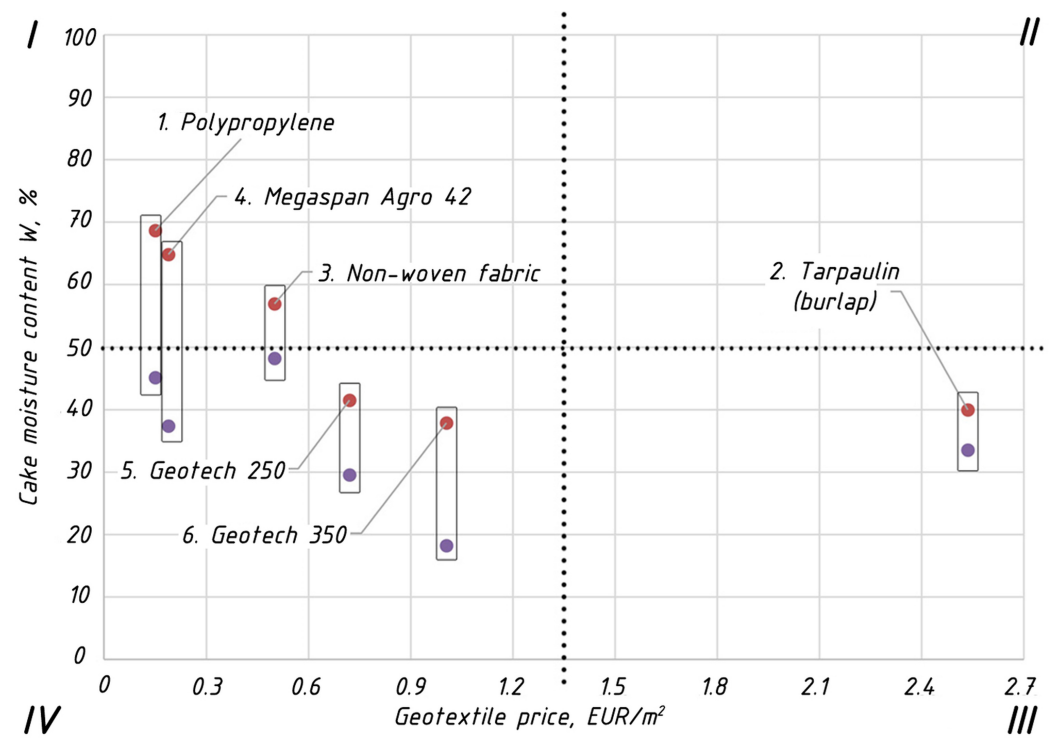

Fig. 3. Matrix "moisture content of dewatered cake - cost of geosynthetics" for different geotextile options: I - cheap materials with a low dewatering rate; II - expensive materials with a low dewatering rate; III - cheap materials with a high dewatering rate; IV - expensive materials with a high dewatering rate; cake moisture is marked with markers: red markers - after 20 days of dewatering; blue markers - after 40 days of dewatering.

\section{Conclusions}

Experimental studies of the process of coal slurry dewatering have proved the possibility of separating four types of geotextile material for dewatering, ranked by the ratio of "moisture of the dried cake - cost of geosynthetics". The results are presented in the form of a matrix. It was found that the highest quality in terms of dewatering rate (dewatering for 20 days to a moisture content of $\mathrm{W}<50 \%$ ) from the entire range of materials are materials that fall into III and IV quadrants of the matrix - № 5 (Geotech 350), № 2 (Geotech 250) and № 6 (tarpaulin). At the same time, the cheapest (matched I and III quadrants of the matrix) in order of increasing cost are materials №№ 1, 3, 4, 5, 6 (polypropylene fabric, Megaspan Agro 40, nonwoven fabric, Geotech 250, Geotech 350).

Recommendations for the dewatering of coal slurry are as follows:

a) the manufacture of SFC required size of the selected material;

b) site preparation of the established sizes;

c) installation of a reinforcing (pipe) grid of the required size for placing an SFC on it with the possibility of subsequent loading into dump trucks;

d) installation of the pipeline network (pump, main and injection pipelines) for filling the SFC;

e) filling the SFC with coal slurry with constant monitoring of uninterrupted and troublefree operation of the pump and pipelines; 
e) control of the dewatering process to establish the conditional (required) humidity of the cake;

g) recycling of cake and SFC.

\section{References}

1. P.C. Lodi, B.S. Bueno, O.M. Vilar, N.S. Correia, Proceedings of the 4th Asian Regional Conference on Geosynthetics, 1, 35-39 (2008)

2. L.D. Suits, Y.G. Hsuan, Geotextiles and Geomembranes, 21, 111-122 (2003)

3. H.J. Kim, T.W. Park, P.R. Dinoy, H.S. Kim, Geosynthetics International, 25:5, 507524. (2018)

4. E.C. Shin, Geosynthetics International, 10:6, 134-141 (2003)

5. D. Leshchinsky, O. Leshchinsky, H.I. Ling, P.A. Gilbert, Journal of Geotechnical Engineering, 122:8, 682-690 (1996)

6. H.J. Kim, M.S. Won, J.C. Jamin, J.H. Joo, Geotextiles and Geomembranes, 44:2, 209218 (2016)

7. K. Terzaghi, Theoretical Soil Mechanics (John Wiley \& Sons, New York, 1943)

8. R.H. Plaut, S. Suherman, Acta Mechanica, 129:3, 207-218 (1998)

9. K. Liao, S.K. Bhatia, Proceedings of NAGS 2005/GRI-19 Cooperative Conference, 1, $1-15(2005)$

10. M. Mikasa. The Consolidation of Soft Clay - A New Consolidation Theory and its Application (Kajima Institution Publishing Co., Ltd., Tokyo, Japan, 1963)

11. M.M. Khachan, S.K. Batia, Geotextiles and Geomembranes, 45:4, 280-293 (2017)

12. T.S. Ingold, The Geotextiles and Geomembranes Manual (Elsevier Advanced Technology, Amsterdam, 1994)

13. N.W.M. John, Geotextiles (Blackie, London, 1987)

14. G.A. Solodov, E.V. Zhbyr, A.V. Papin, A.V. Nevedrov, Bulletin of the Tomsk Polytechnic University, 310:1, 129-132 (2007)

15. S.N. Dyakov, A.V. Papin, A.V. Nevedrov, E.V. Zhbyr, Coke and Chemistry, 55:10, 363-365 (2012)

16. V.A. Kalashnikov, A.V. Gorbachev, Journal of Mining and Geotechnical Engineering, 3, 56-79 (2018)

17. V.Yu. Bazhin, V.B. Kuskov, Ya.V. Kuskova, Ugol', 4, 50-54 (2019) 